\title{
Photosynthesis-controlled calcification in a hypersaline microbial mat
}

\author{
Rebecca Ludwig \\ Max-Planck-Institute for Marine Microbiology, Celsiusstr. 1, D-28359 Bremen, Germany
}

Fuad A. Al-Horani

Marine Science Station, P.O. Box (195) Aqaba, 77110 Jordan

Dirk de Beer and Henk M. Jonkers ${ }^{1}$

Max-Planck-Institute for Marine Microbiology, Celsiusstr. 1, D-28359 Bremen, Germany

\begin{abstract}
We investigated the hypothesis that sulfate reduction rather than oxygenic photosynthesis promotes calcification in a hypersaline microbial mat by increasing the ion concentration product: $\mathrm{ICP}=\left[\mathrm{Ca}^{2+}\right] \times\left[\mathrm{CO}_{3}^{2-}\right]$. Pore-water calcium concentration profiles directly measured with microsensors show that calcium concentration in the photic zone decreased in illuminated mats and increased slightly in dark mats. High pH values in the photic zone of illuminated mats resulted in higher carbonate concentrations $\left(2.25 \mathrm{mmol} \mathrm{L}^{-1}\right)$ than in dark mats $\left(0.75 \mathrm{mmol} \mathrm{L}^{-1}\right)$, although the dissolved inorganic carbon (DIC) pore-water concentration in the former was much lower $(5.9 \mathrm{mmol}$ $\left.\mathrm{L}^{-1}\right)$ than in the latter $\left(9.9 \mathrm{mmol} \mathrm{L} \mathrm{L}^{-1}\right)$. The $\mathrm{pH}$-induced rise in carbonate concentration in the light was the main factor influencing the ICP, while changes in $\mathrm{Ca}^{2+}$ concentration played a subsidiary role. Sulfate reduction did not result in a net $\mathrm{pH}$ increase in these mats, as rates in the photic zone were comparable between illuminated and dark mats ( 4 and $5 \mathrm{nmol} \mathrm{cm}^{-2} \mathrm{~h}^{-1}$, respectively), and $\mathrm{pH}$ increased in illuminated mats but not in dark mats. Calcium carbonate precipitation in the photic zone of these hypersaline mats is primarily controlled by photosynthesisinduced $\mathrm{pH}$ and carbonate concentration increases. However, heterotrophic bacteria, including sulfate reducers, play an important complementary role in calcification because they maintain high concentrations of DIC in the mat pore water.
\end{abstract}

The mechanisms by which biological processes influence calcification in stromatolites and microbial mats are not fully understood, despite its importance in understanding the origin of fossil stromatolites. The present distribution of microbial mats, laminated benthic structures that are regarded as homologs of stromatolites, by far exceeds that of recent stromatolites (Krumbein et al. 1977; Margulis et al. 1980; Des Marais 1990). Although microbial mats occur worldwide in freshwater, marine water, and hypersaline waters (Van Gemerden 1993), the distribution of true microbial stromatolites is confined to a few marine coastal (Reid et al. 2000; Visscher et al. 2000) and freshwater (Laval et al. 2000; Garcia-Pichel et al. 2004) locations. Ancient stromatolites were widely distributed in the Precambrian world and became preserved because they were calcifying. Being the first fossilized evidence for life on earth, knowledge about stromatolite calcification provides a key to elucidate environmental conditions during that time. The extrapolation from calcification in modern communities to stromatolites requires detailed knowledge about how biological processes

\footnotetext{
${ }^{1}$ Corresponding author (hjonkers@mpi-bremen.de).
}

\section{Acknowledgments}

We are indebted to Tim Ferdelman for help with SRR measurements and Michael Böttcher for FTIR analysis. The technicians are thanked for constructing the microsensors. We thank the local authorities in Chiprana for granting permission to access the lake and taking microbial mat samples, and we are particularly grateful to Alfredo Legaz (Guard) for support during fieldwork. We also thank two anonymous reviewers for their constructive remarks. and brine chemistry influence calcification in recent microbial systems. Despite numerous studies (Chafetz and Buczynski 1992; Paerl et al. 2001; Kühl et al. 2003), calcification mechanisms of benthic microbial communities are not fully understood, and results are often controversially discussed (Arp et al. 2003, 2004; Kazmierczak and Kempe 2004). Calcification is the process in which $\mathrm{Ca}^{2+}$ and $\mathrm{CO}_{3}^{2-}$ combine to precipitate as calcium carbonate. Seawater and brines are often supersaturated with respect to calcium carbonate (i.e., the product of calcium and carbonate ions in solution is larger than the stoichiometric solubility product $\left.K_{\mathrm{sp}}^{*}\right)$, where $K_{\mathrm{sp}}^{*}=\left[\mathrm{Ca}^{2+}\right]_{\text {sat }} \times\left[\mathrm{CO}_{3}^{2-}\right]_{\text {sat }}$, and saturation refers to the total equilibrium ion concentration (free plus complexed ions) in a solution (Zeebe and Wolf-Gladrow 2001). The $\mathrm{CaCO}_{3}$ saturation state, $\Omega$, is expressed as follows:

$$
\Omega=\left[\mathrm{Ca}^{2+}\right]\left[\mathrm{CO}_{3}^{2-}\right] / K_{\mathrm{sp}}^{*}
$$

(Zeebe and Wolf-Gladrow 2001). The higher the supersaturation $(\Omega>1)$ with respect to calcium carbonate, the more likely the calcium carbonate precipitates. To calculate the $\mathrm{CaCO}_{3}$ saturation state, ion activities rather than ion concentrations are often considered (Stumm and Morgan 1996). However, the former cannot be directly measured, and the conversion from concentrations to activities at typical seawater salinities, let alone for hypersaline waters, requires uncertain calculations of activity coefficients (Zeebe and WolfGladrow 2001). In this study, we therefore considered the ion concentration product of calcium carbonate $(\mathrm{ICP}=$ $\left.\left[\mathrm{Ca}^{2+}\right] \times\left[\mathrm{CO}_{3}^{2-}\right]\right)$ as an appropriate quantity to clarify calcification mechanisms in microbial mats and stromatolites. 
All microbial processes that increase the ICP of calcium carbonate will increase the likelihood of calcium carbonate precipitation. Calcification in stromatolites or microbial mats has been attributed either to photosynthetic or heterotrophic bacteria. The former group is thought to change the carbonate equilibrium by increasing $\mathrm{pH}$ and carbonate concentration during high rates of $\mathrm{CO}_{2}$ fixation (Riding 2000; Arp et al. 2001). Heterotrophs, and particularly sulfate-reducing bacteria, are thought to increase local calcium concentrations through the mineralization of calcium-binding extracellular polymeric substances (EPSs) (Visscher et al. 2000; Paerl et al. 2001). Furthermore, sulfate reduction might increase DIC, but also $\mathrm{pH}$, and thereby shift the carbonate equilibrium toward the $\mathrm{CO}_{3}^{2-}$ ion (Visscher et al. 1998). Although both mechanisms may account for calcification in microbial mats and stromatolites, direct evidence for either hypothesis has proven difficult to obtain due to the microscale at which these processes occur. Understanding what drives calcification is the first step in determining why only some microbial mats calcify, while other mats in comparable environments do not. Microsensor techniques may overcome methodological restrictions imposed by the microscale and are the ideal tool to study the microenvironmental controls of calcification potential in mats or stromatolites (Kühl et al. 2003; GarciaPichel et al. 2004). In recent studies, for example, the calcification mechanism in scleractinic corals was elucidated by application of microsensors (de Beer et al. 2000; Al-Horani et al. 2003). The goal of our study was to elucidate whether phototrophy or heterotrophy (by sulfate-reducing bacteria) increased the ICP and thereby induced calcification in a hypersaline microbial mat. Mats from "La Salada de Chiprana," northeastern Spain, were chosen as a model system, as both oxygenic photosynthesis and sulfate reduction are known to occur at high rates. The spatial and temporal distribution of calcification was determined for the first time using $\mathrm{Ca}^{2+}$ microsensors to measure depth profiles of $\mathrm{Ca}^{2+}$ pore-water concentration in light and dark incubated mats. The other component of the ICP $\left[\mathrm{CO}_{3}^{2-}\right]$ was calculated from DIC pore-water and $\mathrm{pH}$ microsensor data. In addition, rates of the processes potentially involved in calcification, sulfate reduction, and oxygenic photosynthesis were measured using ${ }^{35} \mathrm{SO}_{4}^{2-}$ and fast-responding oxygen microsensors, respectively.

\section{Materials and methods}

Microbial mat description-Microbial mat samples were collected in May 2001 from "La Salada de Chiprana" (Lake Chiprana) located in northeastern Spain $\left(41^{\circ} 14^{\prime} \mathrm{N}, 0^{\circ} 10^{\prime} \mathrm{W}\right)$. The lake has a total surface area of $0.31 \mathrm{~km}^{2}$ and lies on the Upper Oligocene-Miocene Caspe Formation that is mainly composed of sand stones and silt stones. The average salinity of the lake water is around 78, and the ionic composition is dominated by magnesium sulfate $\left(\mathrm{SO}_{4}^{2-} 500 \mathrm{mmol} \mathrm{L}{ }^{-1}\right.$; $\mathrm{Mg}^{2+} 320 \mathrm{mmol} \mathrm{L}{ }^{-1}$ ). A detailed description of the water composition and the microbial mat community composition has been published (Jonkers et al. 2003). The mats, collected from a water depth of approximately $40 \mathrm{~cm}$, were composed of visually distinct horizontal layers that were characterized

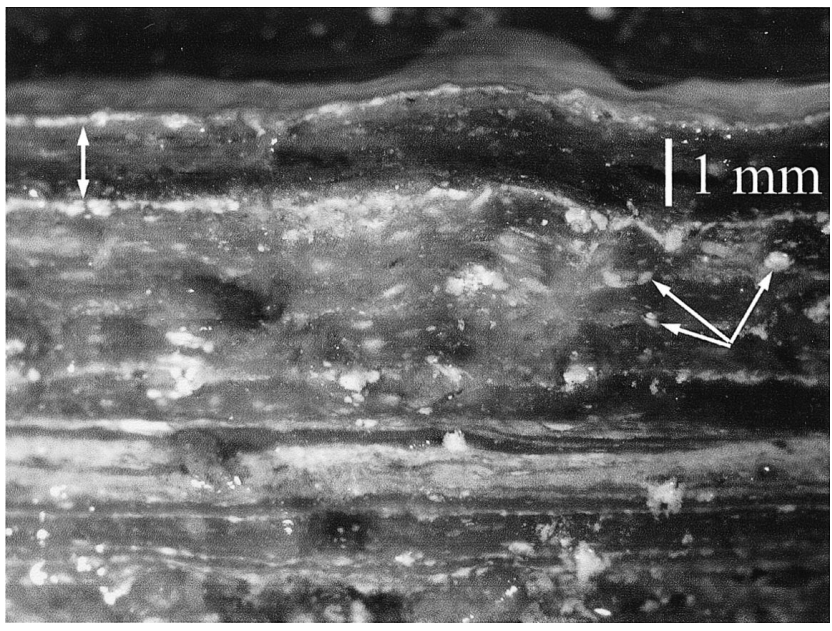

Fig. 1. Picture of laminated Lake Chiprana mat with clearly visible calcium carbonate layers (double-headed arrow) and interspersed crystals (single-headed arrows).

by various species of diatoms, Chloroflexus-like bacteria, cyanobacteria, and calcium carbonate precipitates (Fig. 1). Abundant populations of aerobic heterotrophic, purple and colorless sulfur, and sulfate-reducing bacteria were also present (Jonkers et al. 2003). Microbial mat samples were transported to Bremen, Germany, and incubated under natural light conditions in a greenhouse in aquaria filled with water from the sampling site. Microsensor measurements of oxygen and photosynthesis profiles, which were routinely measured during the incubation period, were not different from those measured in situ under similar light conditions, which indicates that physiological processes did not change to a major extent during the laboratory incubations.

Microsensor measurements-Microbial mat cores $(\varnothing 5 \mathrm{~cm}$; $1.5 \mathrm{~cm}$ thick) taken from the greenhouse-incubated mats were transferred to the laboratory to a temperature-controlled flow-through chamber. The mat pieces were subsequently incubated in the dark or in the light $(500,1,000 \mu \mathrm{mol}$ photons $\mathrm{m}^{-2} \mathrm{~s}^{-1}$ ) using a fiber-optic lamp (KL 1500, Schott). After steady-state oxygen profiles were obtained, microsensor profiles of oxygen, $\mathrm{pH}$, calcium, and $\mathrm{H}_{2} \mathrm{~S}$ were measured sequentially at the same spot. We have no evidence that the repeated penetration induced an artifact, as the initial profiles are not different from the profiles measured later at the same spot. Locating the measuring spot, as well as determining the surface, was achieved with the help of a dissection scope (SV6, Zeiss). Preparation and calibration of oxygen microsensors (tip diameters of $10 \mu \mathrm{m}$ ) were performed according to Revsbech (1989). Preparation of $\mathrm{H}_{2} \mathrm{~S}$ microsensors (tip diameters of $15 \mu \mathrm{m}$ ) was performed according to Kühl et al. (1998), and the calibration procedure is described in Wieland and Kühl (2000). pH and calcium concentration were measured with ion-specific liquid ion-exchange (LIX) glass microsensors with tip diameters of $10 \mu \mathrm{m}$ (de Beer et al. 2000). In addition to microsensor measurements, $\mathrm{Ca}^{2+}$ concentrations in pore-water samples obtained by centrifugation of 2-mm discrete depth layers were determined by atomic absorption spectroscopy (AAS). Gross photosynthesis rates 
were measured with fast oxygen microsensors that had a tip diameter of $5 \mu \mathrm{m}$ using the light: dark shift method according to Revsbech and Jørgensen (1983). Profiles of all parameters were measured at least threefold in mats incubated under the specified light conditions.

Estimation of pore-water carbonate concentrations-Carbonate concentrations in microbial mat pore water and overlying water were estimated from measured $\mathrm{pH}$ profiles and dissolved inorganic carbon (DIC) concentrations. DIC porewater concentrations were measured in aliquots extracted from distinct 1-mm mat slices using a Shimadzu TOC5050A Total Organic Carbon Analyzer. Hereto, intact mat cores were preincubated for $5 \mathrm{~h}$ either in the dark or in the light at $500 \mu \mathrm{mol}$ photons $\mathrm{m}^{-2} \mathrm{~s}^{-1}$. Cores were subsequently sliced in $1-\mathrm{mm}$ intervals, and these were immediately centrifuged mildly $(10 \mathrm{~min}$ at $6,000 \times \mathrm{g})$ to obtain supernatant (pore water) without disrupting cells. The carbonate ion concentration at distinct depth intervals was estimated from the measured $\mathrm{pH}$ profiles and DIC concentrations in dark and light incubated mats according to the following:

$$
\left[\mathrm{CO}_{3}^{2-}\right]=[\mathrm{DIC}] /\left(1+10^{\left(-\mathrm{ph}+\mathrm{p} K_{2}\right)}\right)
$$

with a $\mathrm{p} K_{2}$ value of 8.94 (calculated for $20^{\circ} \mathrm{C}$ and a salinity of 80 as recommended in Zeebe and Wolf-Gladrow [2001]). Water temperature in the laboratory set-up during light and dark incubation was kept constant at $20^{\circ} \mathrm{C}$. The pore-water $\mathrm{CO}_{2}$ concentrations were insignificant at the prevailing porewater $\mathrm{pH}$ values and could thus be ignored.

Sulfate reduction rates in dark and light incubated matsSulfate reduction rates (SRRs) were measured and calculated using a modification of the whole-core tracer incubation method (Jørgensen 1978). Microbial mat cores of $\varnothing 1.5 \mathrm{~cm}$ and $\geq 1$-cm depth were incubated with $2 \mathrm{~mL}$ of in situ water overlying the core at $20^{\circ} \mathrm{C}$ either at $500 \mu \mathrm{mol}$ photons $\mathrm{m}^{-2}$ $\mathrm{s}^{-1}$ or in the dark. Fifty microliters of radiotracer ${ }^{35} \mathrm{SO}_{4}^{2-}$; $0.2 \mathrm{MBq} \mathrm{mL}{ }^{-1}$, Amersham) was injected vertically per core. Ten injections of $5 \mu \mathrm{L}$ each were evenly distributed throughout the core to improve label distribution. The homogeneous distribution of labels after 10 min was confirmed by imaging the label distribution in 1-mm slices with a PhosphorImager (Molecular Dynamics). After incubation (0, 10, 15, 20, 40, and $60 \mathrm{~min}$ ), sulfate reduction was terminated by placing the intact core in liquid $\mathrm{N}_{2}$. Cores were subsequently sliced into 1-mm horizontal slices using a cryomicrotom (microm HM $505 \mathrm{E},-30^{\circ} \mathrm{C}$ ) and fixed in $20 \% \mathrm{ZnAc}$. Samples were processed using the cold chromium distillation procedure (Kallmeyer et al. 2004), which is based on the single-step chromium reduction method as described by Fossing and Jørgensen (1989). The activities of ${ }^{35} \mathrm{SO}_{4}^{2-}$ and TRIS (total reduced inorganic sulfur) were determined using a liquid scintillation counter (2500 TR, Packard), and the scintillation cocktail used was Lumasafe Plus (Lumac BV, Holland). Sulfate was determined by nonsuppressed ion-chromatography and conductivity detection (model WISP 712, Waters).

${ }^{45} \mathrm{Ca}$ radioisotope incubation of mat samples-One-centimeter-thick cores were sampled from the greenhouse-incubated mats using cutoff plastic syringes $(\varnothing 1.6 \mathrm{~cm})$. Filtered
$(0.2 \mu \mathrm{m} ; 4 \mathrm{~mL})$ Chiprana lake water was carefully added on top of the mat samples, and radioactive incubations were subsequently performed with these cores. Radioactive calcium $\left({ }^{45} \mathrm{Ca}^{2+}\right.$, Amersham Pharmacia Biotech) was added as the tracer $\left(3 \mathrm{KBq} \mathrm{mL}^{-1}\right)$ to the water phase and carefully mixed. The amount of radiotracer added was negligible compared to the calcium concentration of the Chiprana water (17 mmol L ${ }^{-1}$ ). Three series of incubations were run in parallel-two biotic (light and dark) and one killed control (light plus formaldehyde, $4 \%$ final concentration) at room temperature. Light incubated mats were illuminated with a Schott KL 1500 fiber-optic lamp $\left(500 \mu \mathrm{mol}\right.$ photons $\left.\mathrm{m}^{-2} \mathrm{~s}^{-1}\right)$. Each series consisted of three mat cores, which were incubated for distinct periods $(1.25,3.25$, and $6.25 \mathrm{~h})$. The incubations were terminated by the addition of formaldehyde (4\% final concentration) to the water phase. After $5 \mathrm{~min}$, the supernatant water of formaldehyde-fixed cores was removed, and the intact mat cores were washed three times with 4-mL aliquots of $0.2-\mu \mathrm{m}$ filtered Chiprana lake water and subsequently frozen overnight $\left(-20^{\circ} \mathrm{C}\right)$. Frozen mat samples were vertically cut in 1-mm-thick slices, which were additionally washed three times in $0.2-\mu \mathrm{m}$ filtered Chiprana lake water before being air dried on microscope slides. During the washing and microscopic slide preparation procedure, the originally compact microbial mat slices expanded to almost double their size, as determined by surface area measurements. This expansion was corrected for in all presented data. Samples were covered with scintillation foil and analyzed by beta microimaging. Three mat slices were analyzed for each experimental condition. Uptake and spatial distribution of radioactive calcium was quantified using a beta emission microimager (Micro Imager, Biospace Mesures). This type of imager allows the quantification of radioactive slides with a spatial resolution of $10 \mu \mathrm{m}$; see Laniece et al. (1998) for a detailed description of the beta microimager working principle. The scan time for each sample was fixed at 30 min. Obtained images were analyzed with the Betavision software package provided by the manufacturer, which also allows surface determination by analyzing a simultaneously taken photograph. In addition to total counts, counts were horizontally averaged over a width of $4 \mathrm{~mm}$ parallel to the surface for depth intervals of $100 \mu \mathrm{m}$ down to 2-mm depth. Because the scan time was fixed and the mat sizes were comparable for all samples and experimental conditions, obtained total surface counts and depth-integrated counts could be directly compared among all samples. Theoretical distribution of ${ }^{45} \mathrm{Ca}^{2+}$ radiotracer in the microbial mat in space and time was estimated using the diffusion equation below for a semi-infinite medium after Crank (1975). This equation applies to conditions where the concentration at the boundary is kept at a constant concentration $C_{0}$, and the initial concentration is 0 throughout the medium.

$$
C_{t}=C_{0} \operatorname{erfc}\left(x \times(2 \sqrt{D t})^{-1}\right)
$$

where $C_{t}$ is the concentration at a given time, $C_{0}$ is the initial concentration, $D$ is the diffusion coefficient at $20^{\circ} \mathrm{C}, t$ is the time, $x$ is the depth, and erfc is the error function complement.

According to these calculations, the radiotracer concentra- 


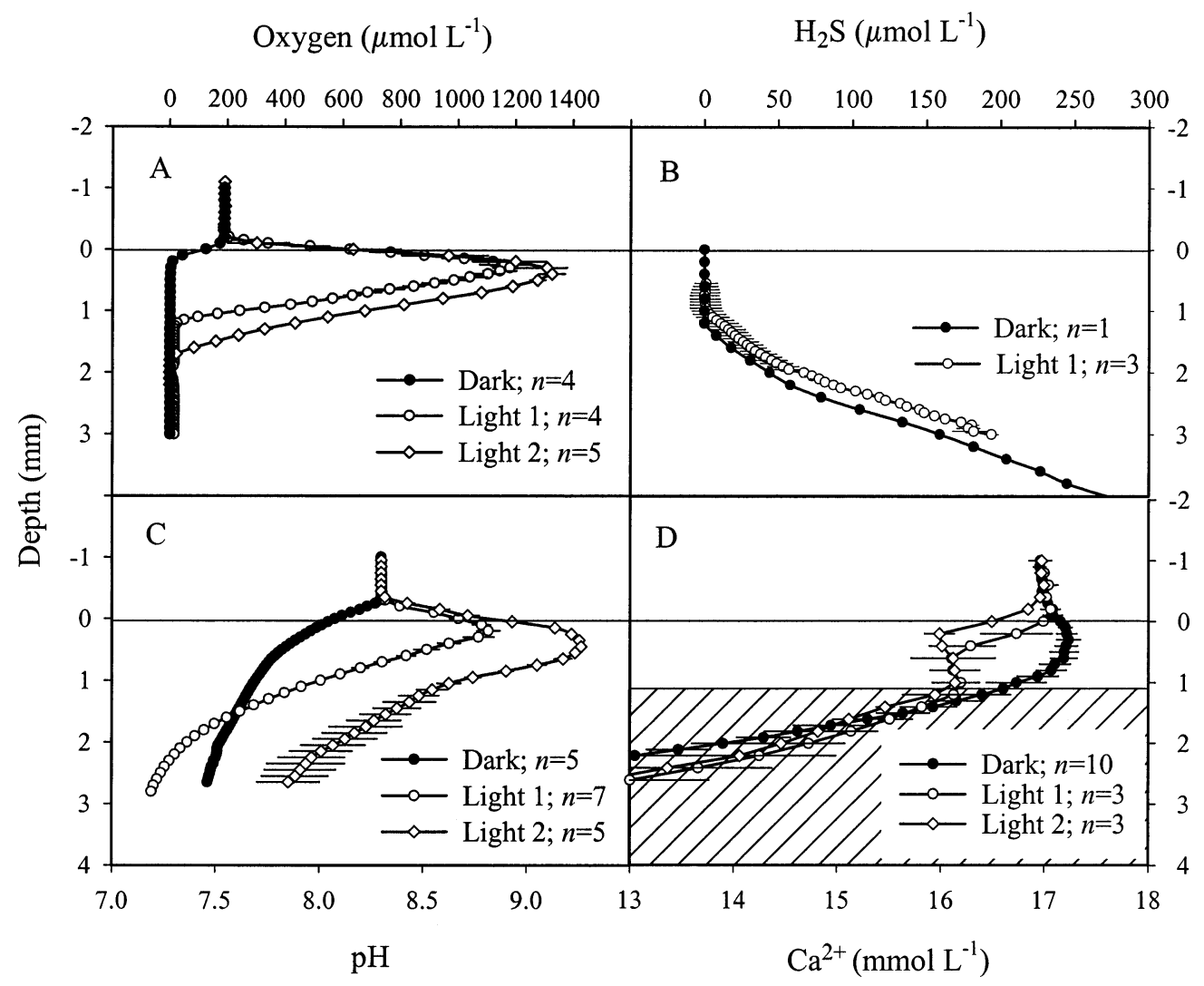

Fig. 2. Averaged microsensor profiles of (A) $\mathrm{O}_{2}$, (B) $\mathrm{H}_{2} \mathrm{~S}$, (C) $\mathrm{pH}$, and (D) $\mathrm{Ca}^{2+} \pm$ standard deviation measured in dark and light incubated mats (light 1 corresponds to a light intensity of 500 $\mu \mathrm{mol}$ quanta $\mathrm{m}^{-2} \mathrm{~s}^{-1}$; light 2 corresponds to $1,000 \mu \mathrm{mol}$ quanta $\mathrm{m}^{-2} \mathrm{~s}^{-1}$ ). The number of replicates measured is indicated in the legend. Panel B: The $\mathrm{H}_{2} \mathrm{~S}$ electrodes were light sensitive, despite a black coat to minimize this effect. Therefore, only data points deeper than $0.55 \mathrm{~mm}$ were considered. The hatched part of panel D represents $\mathrm{Ca}^{2+}$ microsensor measurements in sulfide containing layers.

tion at 2-mm depth after a 6-h incubation was $80 \%$ of the concentration in the overlying water.

\section{Results}

Location and identification of carbonates-A vertical cut through the studied mat (Fig. 1) shows that carbonate crystals in Lake Chiprana mats form discrete layers of approximately $100-\mu \mathrm{m}$ thickness or are interspersed as grains of up to $500 \mu \mathrm{m}$ in diameter. The uppermost continuous layers of deposits are located at 1-mm depth and at the mat surface. Deeper layers are found at 4 and $6 \mathrm{~mm}$, the strata that most likely contain older mat layers. FTIR (Fourier Transform infrared spectroscopy) (Böttcher et al. 1997) showed that 80\% of the carbonate fraction from the photic zone $(0-3 \mathrm{~mm})$ consisted of aragonite, with a minor fraction of calcite.

Microsensor profiles-Microsensor measurements showed that the most pronounced differences in $\mathrm{pH}, \mathrm{Ca}^{2+}$, and $\mathrm{O}_{2}$ between dark and light incubations occurred in the top millimeter of the mat (Fig. 2). Photosynthetic oxygen evolution led to a supersaturation of up to five times air saturation in the top millimeters of the mat. The depth of the oxygen concentration maximum coincided with a $\mathrm{pH}$ maximum of around 9 in the top millimeters of the mat. Both $\mathrm{pH}$ and oxygen concentration increased with increasing light intensity. The lowest calcium concentrations in illuminated mats were found at the same depth as the oxygen and $\mathrm{pH}$ maxima. Calcium concentration decreased from $17 \mathrm{mmol}$ $\mathrm{L}^{-1}$ in the overlying water to approximately $16 \mathrm{mmol} \mathrm{L}^{-1}$ at 0.4-mm depth, with the lowest calcium concentrations measured during incubations at higher light intensities. Unfortunately, measurements of calcium concentration in deeper anoxic layers were influenced by the presence of sulfide, which induced a strong negative drift of the signal. Therefore, only readings from the upper sulfide-free mat were used. Free sulfide could be detected in deeper layers $(>1$ $\mathrm{mm}$ ) of both dark and light incubated mats (Fig. 2B). AAS on extracted pore water showed that $\mathrm{Ca}^{2+}$ concentrations in deeper mat layers remained constant at $16 \pm 0.5 \mathrm{mmol} \mathrm{L}^{-1}$. For ICP calculations at depths $>1 \mathrm{~mm}, \mathrm{a} \mathrm{Ca}^{2+}$ concentration of $16 \mathrm{mmol} \mathrm{L}^{-1}$ was used.

In the dark, oxygen penetration decreased to $0.3 \mathrm{~mm}$, compared to $1.8 \mathrm{~mm}$ at $1,000 \mu \mathrm{mol}$ photons $\mathrm{m}^{-2} \mathrm{~s}^{-1}$ (Fig. $2 \mathrm{~A})$. The $\mathrm{pH}$ profiles in dark incubated mats showed a continuous decrease in $\mathrm{pH}$ with depth, while calcium concentrations in the top millimeter showed a slight increase of up 

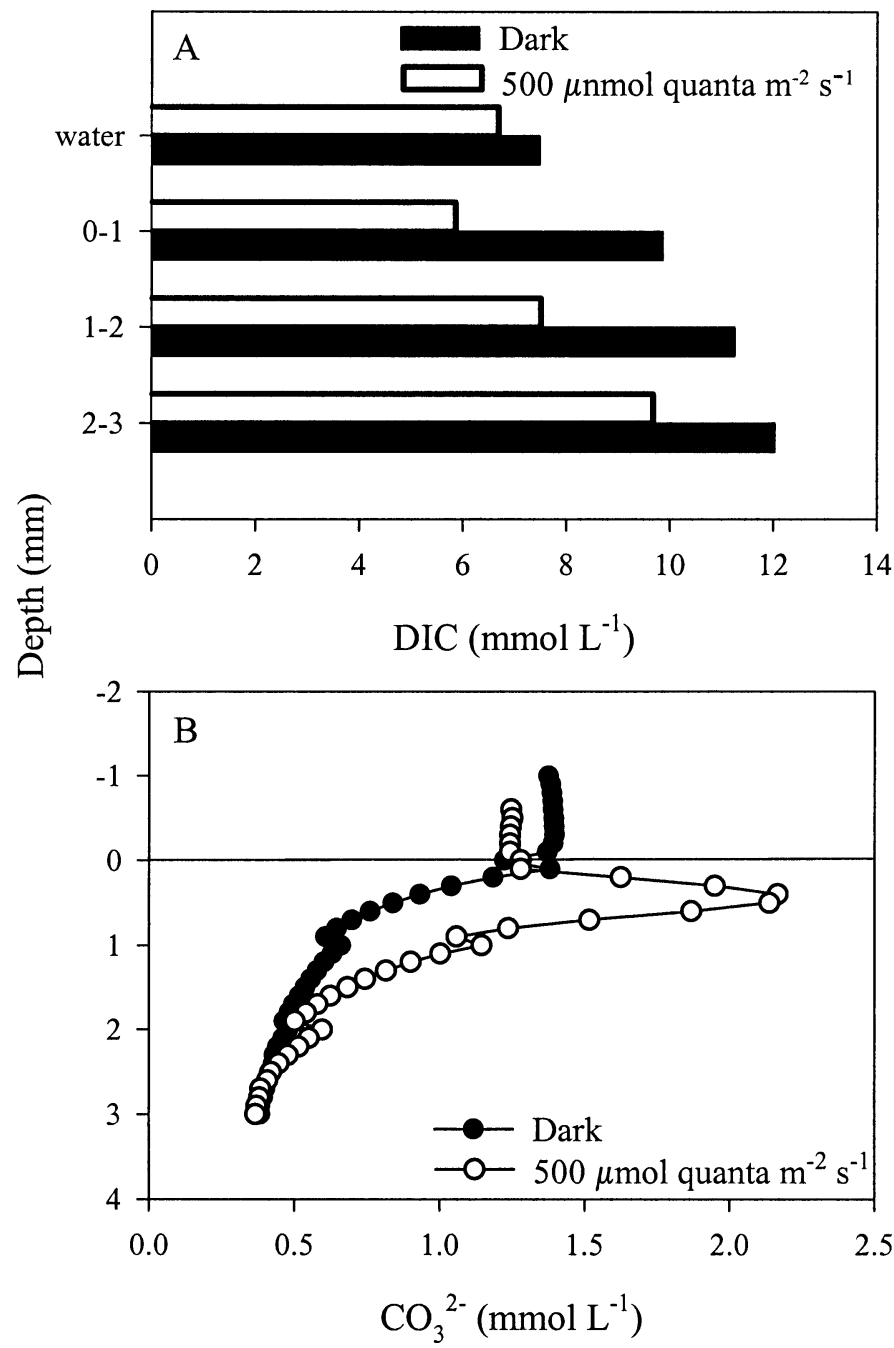

Fig. 3. Measured pore-water concentrations of (A) DIC and (B) calculated concentrations of $\mathrm{CO}_{3}^{2-}$ in dark and light incubated mats.

to $0.1 \mathrm{mmol} \mathrm{L} \mathrm{L}^{-1}$ compared to the $1 \mathrm{mmol} \mathrm{L}^{-1}$ decrease in the light.

Pore-water profiles-Pore-water DIC concentration at $500 \mu \mathrm{mol}$ quanta $\mathrm{m}^{-2} \mathrm{~s}^{-1}$ reached its lowest value in the 1$\mathrm{mm}$ horizon $\left(6 \mathrm{mmol} \mathrm{L}{ }^{-1}\right)$, about $1 \mathrm{mmol} \mathrm{L}^{-1}$ lower than in the overlying water (Fig. 3A). In dark incubated mats, DIC concentrations were considerably higher and increased continuously with depth (Fig. 3A). The shape of the calculated $\mathrm{CO}_{3}^{2-}$ concentration profiles (Fig. 3B), however, appeared to be completely different from the DIC profiles. Maximal $\mathrm{CO}_{3}^{2-}$ concentrations occurred in the top 1-mm layer in light incubated mats, the layer where DIC reached its minimum. The $\mathrm{CO}_{3}^{2-}$ concentration in this layer was almost twice as high as in any other layer in light or dark incubated mats. In the dark, the highest $\mathrm{CO}_{3}^{2-}$ concentration was in the overlying water.

The profile of the ICP of calcium carbonate $\left(\left[\mathrm{Ca}^{2+}\right] \times\right.$ $\left[\mathrm{CO}_{3}^{2-}\right]$ ) (Fig. 4) has virtually the same shape as the $\mathrm{CO}_{3}^{2-}$ concentration pore-water profile, which shows clearly that the former is chiefly determined by $\mathrm{CO}_{3}^{2-}$ and not by $\mathrm{Ca}^{2+}$

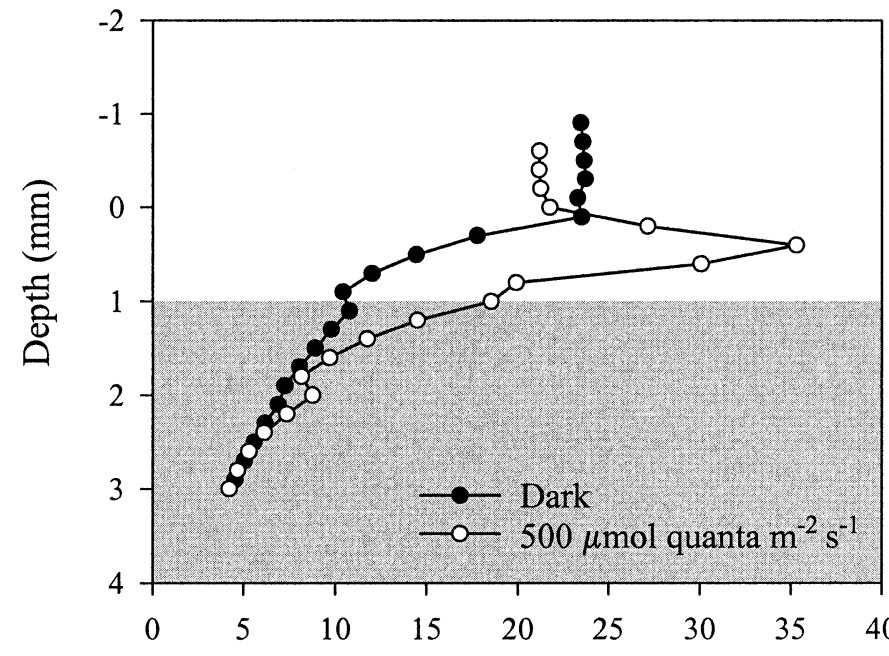

ICP of calcium carbonate $\left(\mathrm{mmol}^{2} \mathrm{~L}^{-2}\right)$

Fig. 4. Ion concentration product of calcium carbonate in dark and light incubated mats based on $\mathrm{Ca}^{2+}$ microsensor measurements and $\mathrm{CO}_{3}^{2-}$ calculations. Shaded area denotes where $\mathrm{Ca}^{2+}$ concentrations were not based on microsensor but on atomic absorption spectroscopy data.

concentration. Maximal values were reached at a depth of $0.5 \mathrm{~mm}$ in illuminated mats, while in dark incubated mats, values were consistently lower than in the overlying water.

Radiotracer incubations-Light incubated mats incorporated significantly more ${ }^{45} \mathrm{Ca}^{2+}$ radioisotope than dark incubated mats or killed controls (Fig. 5). The spatial distribution of ${ }^{45} \mathrm{Ca}^{2+}$ showed highest incorporation in the surface layer of light incubated mats (Fig. 5). Dark incubated mats also incorporated radiotracer, but uptake rates were significantly lower than in light incubated mats and comparable to passive adsorption by killed controls.

Sulfate reduction rates-Incubation times of $\leq 1 \mathrm{~h}$ were chosen to reduce sulfide reoxidation (Canfield and Des Marais 1991), and indeed, incubation times had no discernible effect on SRRs (data not shown). However, SRRs showed a high heterogeneity between different cores (Fig. 6). This may reflect a high spatial variability of microbial mats, but it might also partly be due to the irregular sediment surface, with the consequence that slicing not always followed the layering of the mat. Maximal rates in all replicates, both during light and dark incubation, were around 3-mm depth (Fig. 6).

Simultaneously measured oxygen microsensor profiles in replicate cores showed that the oxic zone comprised the first 2-2.5 mm; thus, the highest SRRs were at the oxic-anoxic interface. The depth-integrated $(0-6 \mathrm{~mm})$ SRRs averaged over all incubation times amounted to $7 \mathrm{nmol} \mathrm{cm} \mathrm{cm}^{-2} \mathrm{~h}^{-1}$ in

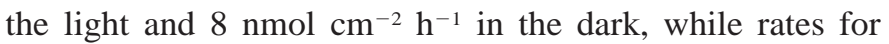
the photic zone $(0-3 \mathrm{~mm})$ were 4 and $5 \mathrm{nmol} \mathrm{cm}^{-2} \mathrm{~h}^{-1}$, respectively. Thus, SRRs were comparable between light and dark incubated mats. The calculated areal gross photosynthesis rate at $500 \mu \mathrm{mol}$ photons $\mathrm{m}^{-2} \mathrm{~s}^{-1}$ was $450 \mathrm{nmol} \mathrm{O}_{2}$ 

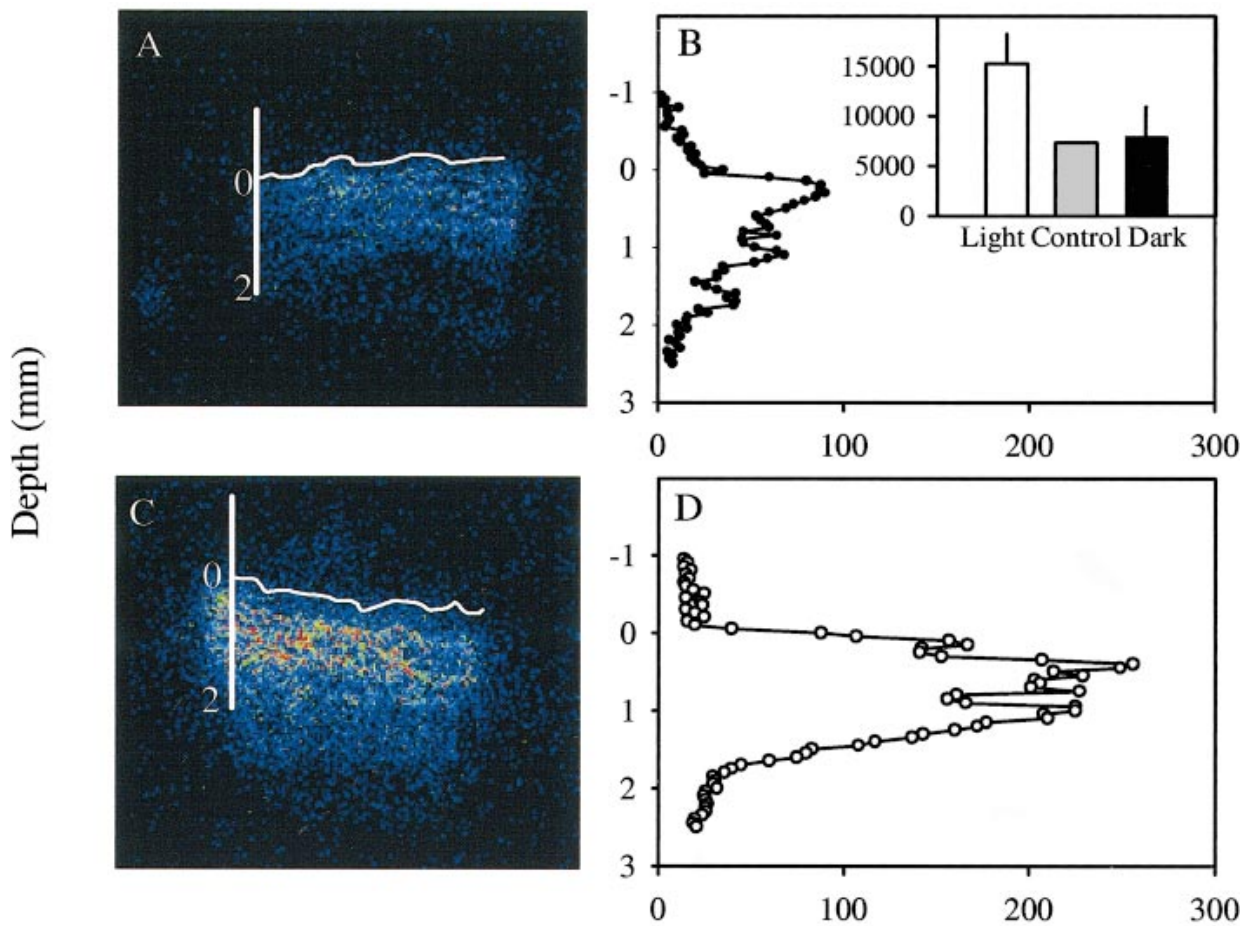

B-counts

Fig. 5. Spatial distribution of incorporated ${ }^{45} \mathrm{Ca}^{2+}$ after a 6.25 -h radiotracer incubation in (A, B) dark and (C, D) light $\left(500 \mu \mathrm{mol}\right.$ quanta $\left.\mathrm{m}^{-2} \mathrm{~s}^{-1}\right)$ incubated mats visualized by $\beta$-imaging (A, C). For depth profiles of ${ }^{45} \mathrm{Ca}^{2+}$ incorporation, signals were averaged over $0.1 \times 4 \mathrm{~mm}(\mathrm{~h} \times \mathrm{w})$ $(\mathrm{B}, \mathrm{D})$. The inset in panel $\mathrm{B}$ shows total counts averaged over $2 \times 4 \mathrm{~mm}(\mathrm{~h} \times \mathrm{w})$. The mat expanded during the necessary washing steps, and this expansion was corrected for by adjusting the depth scale. The white line represents the mat surface.

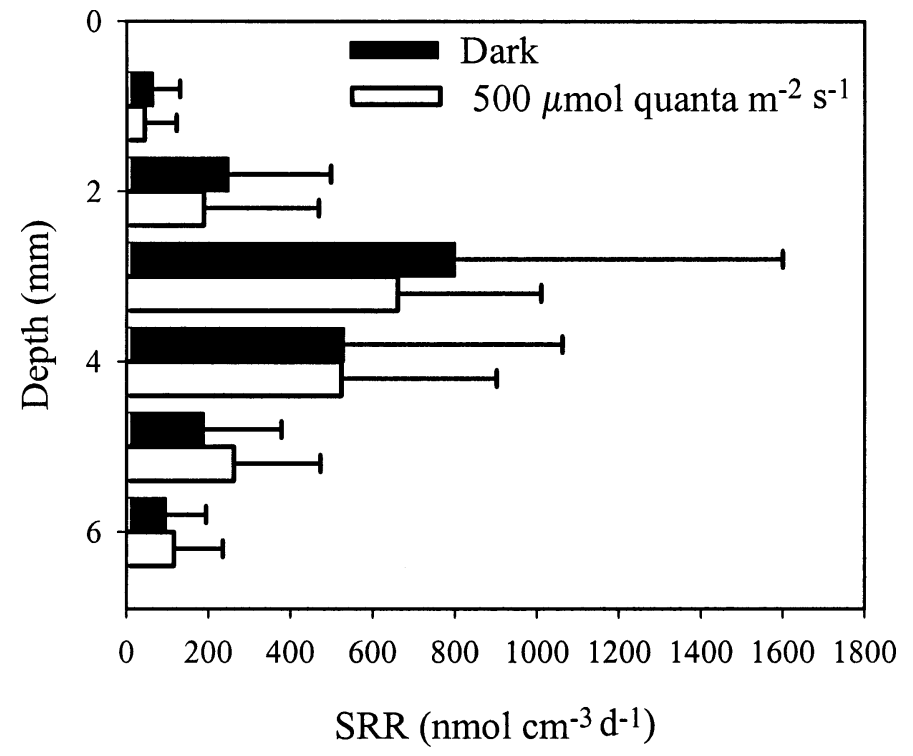

Fig. 6. Depth profile of SRRs measured in dark and light incubated mats. Bars represent the average of measurements with five different incubation times and three replicates each. $\mathrm{cm}^{-2} \mathrm{~h}^{-1}$, which is equivalent to $450 \mathrm{nmol} \mathrm{CH}_{2} \mathrm{O}$ units $\mathrm{cm}^{-2}$ $\mathrm{h}^{-1}$. SRRs in the photic zone of light incubated mats amount-

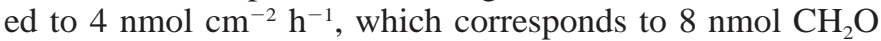
units $\mathrm{cm}^{-2} \mathrm{~h}^{-1}$. Thus, in the photic zone, around 60 times more carbon was fixed by photosynthesis than potentially converted by sulfate reduction.

\section{Discussion}

Chiprana microbial mats proved to be a highly suitable model system to compare the influence of sulfate reduction and oxygenic photosynthesis on calcification, as both processes occur simultaneously in the light, while the former only takes place in the dark. Therefore, the key to analyzing the data is to focus on the differences between light and dark incubated mats. Many previous studies have provided valuable insights in calcification mechanisms of microbial mats (Reid et al. 2000; Visscher et al. 2000; Arp et al. 2001), but the exact reason why calcification occurs remains under discussion (Arp et al. 2003, 2004; Kazmierczak and Kempe 2004). Part of this emerges from the fact that two parameters crucial for calcification, calcium and carbonate concentration, have never been directly measured at sufficient spatial resolution in microbial mats. In this study, we therefore determined both concentrations and followed the influence of light on $\mathrm{Ca}^{2+}$ and $\mathrm{CO}_{3}^{2-}$ profiles. By applying $\mathrm{Ca}^{2+}$ micro- 
sensors within microbial mats, we could visualize changes in calcium fluxes between light and dark incubated mats. While $\mathrm{Ca}^{2+}$ concentration in light incubated mats decreased in the photic zone by almost $1 \mathrm{mmol} \mathrm{L}^{-1}$, in dark incubated mats, concentration in this layer increased. The calcium increase in the dark can be explained by a release of calcium from EPSs when the latter are degraded by heterotrophs, while the decrease in $\mathrm{Ca}^{2+}$ concentration in the light may reflect binding to EPSs, freshly produced by phototrophs (Paerl et al. 2001). The daily calcium dynamic in EPS-rich layers, with relatively low concentrations during the day and higher concentrations at night, would thus reflect $\mathrm{Ca}^{2+}$ binding to and $\mathrm{Ca}^{2+}$ release from EPSs, respectively. Paerl et al. (2001) suggested that such a release of $\mathrm{Ca}^{2+}$ from EPSs increases $\mathrm{Ca}^{2+}$ pore-water concentration and drives calcification in stromatolites from the Bahamas, as the highest metabolic rates of heterotrophs coincided with areas of high $\mathrm{CaCO}_{3}$ precipitation. In our study, the observed uptake of ${ }^{45} \mathrm{Ca}^{2+}$ in the light is also in agreement with the EPS theory, as the incorporated $\mathrm{Ca}^{2+}$ may have been bound to EPSs that are copiously produced in Chiprana mats, rather than precipitated as $\mathrm{CaCO}_{3}$. Alternatively, the measured decrease of $\mathrm{Ca}^{2+}$ in the light (Fig. 2D) could have resulted directly from a decrease in calcium pore-water concentration caused by the calcifying activity of Chiprana mats.

Calcification does not depend only on the concentration of $\mathrm{Ca}^{2+}$ but also on $\mathrm{CO}_{3}^{2-}$ concentration. Therefore, the ICP, which includes both quantities, has to be considered when unraveling the calcification mechanism. The striking similarity in profile shape between the $\mathrm{CO}_{3}^{2-}$ and ICP profile illustrates that, in the photic zone, changes in $\mathrm{CO}_{3}^{2-}$ concentration have a pronounced influence on the ICP (Figs. 3, 4). In Chiprana mats, changes in $\mathrm{Ca}^{2+}$ concentration, potentially induced by diel changes in EPS content, on the other hand, are not reflected in the ICP (Figs. 2B, 4). It thus appears that in Chiprana mats, $\mathrm{CO}_{3}^{2-}$ concentration rather than $\mathrm{Ca}^{2+}$ concentration influences calcification rates. This is not surprising, considering that about 20 times more $\mathrm{Ca}^{2+}$ than $\mathrm{CO}_{3}^{2-}$ is present in the pore water, so that changes in $\mathrm{CO}_{3}^{2-}$ have a 20 times stronger effect on the ICP than the same molar changes in $\mathrm{Ca}^{2+}$ concentration.

The processes affecting $\mathrm{CO}_{3}^{2-}$ concentration rather than $\mathrm{Ca}^{2+}$ concentration determine calcification rates in Chiprana mats. Calculating $\mathrm{CO}_{3}^{2-}$ from $\mathrm{pH}$ and DIC shows clearly that in Chiprana water, changes in $\mathrm{pH}$ have a strong effect on the $\mathrm{CO}_{3}^{2-}$ concentration. The $\mathrm{pH}$ increase in the photic zone of Chiprana mats (Fig. 2C) might be the result of high rates of photosynthetic carbon fixation, which removes $\mathrm{HCO}_{3}^{-}$and $\mathrm{CO}_{2}$. However, several studies report that sulfate reduction may also induce $\mathrm{pH}$ increases and thereby promote calcification in microbial mats (Visscher et al. 1998, 2000; Castanier et al. 1999). Sulfate reduction has been reported to reach high rates in the fully oxygenated parts of illuminated microbial mats (Canfield and Des Marais 1991; Fründ and Cohen 1992; Jørgensen 1994). We also detected high rates of sulfate reduction in the fully oxygenated upper layer of illuminated Lake Chiprana mats. Maximal volumetric rates of $0.7 \mu \mathrm{mol} \mathrm{cm} \mathrm{cm}^{-3} \mathrm{~d}^{-1}$ in the light and $0.8 \mu \mathrm{mol} \mathrm{cm} \mathrm{cm}^{-3} \mathrm{~d}^{-1}$ in the dark are higher than SRRs measured in calcifying stro-

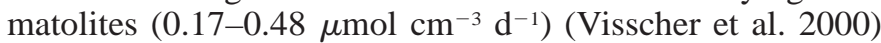

and are in the same range as rates measured in other mat systems (Canfield and Des Marais 1991; Fründ and Cohen 1992; Jørgensen 1994). SRRs in light and dark incubated Chiprana mats were comparable. However, as $\mathrm{pH}$ increased in light incubated mats but not in dark incubated mats (Fig. 2C), we conclude that sulfate reduction apparently did not contribute, to a major extent, to $\mathrm{pH}$ increases in illuminated mats and thus to increased ICP values. Oxygenic photosynthesis, however, apparently drives calcification in the photic zone of Chiprana mats, as this process primarily increases the ICP by increasing $\mathrm{pH}$ and thus $\mathrm{CO}_{3}^{2-}$ concentrations. Thus, all our data indicate that calcification in the top 1-mm of the mat, the same region where aragonite deposits were indeed found, is driven by a photosynthetically induced $\mathrm{pH}$ increase. Interestingly, the location of photosynthetically precipitated carbonates in these natural mats, at the basis of the uppermost cyanobacterial layer, was similar to what was observed in artificial laboratory-grown mats (Kühl et al. 2003). The photosynthetically induced rise in $\mathrm{pH}$, which increased $\mathrm{CO}_{3}^{2-}$ concentrations, occurred despite high concentrations of DIC, which have been thought to buffer photosynthetically induced $\mathrm{pH}$ changes and thereby reduce the ability of phototrophs to induce calcification in high DIC environments (Arp et al. 2003).

This study demonstrates that, on the basis of $\mathrm{Ca}^{2+}$ microsensor profiles alone, no conclusion about the mechanism of calcification in Chiprana mats could have been drawn. Parallel measurements of $\mathrm{Ca}^{2+}, \mathrm{pH}$, and DIC concentration provided evidence that calcification in Lake Chiprana mats occurs in light incubated mats. Only in the photic zone of illuminated mats does the ICP reach the highest values, being almost twice as high as in dark incubated mats. The decrease in $\mathrm{Ca}^{2+}$ concentration measured by the microsensors in light incubated mats, therefore, most likely directly reflects calcification activity. Consequently, $\mathrm{Ca}^{2+}$ microsensors can be used to directly study the calcification process in microbial mats; however, only in combination with measurements of $\mathrm{pH}$ and $\mathrm{DIC}\left(\mathrm{CO}_{3}^{2-}\right)$ dynamics can the factors driving calcification be identified.

Although oxygenic photosynthesis, rather than sulfate reduction, was identified as the driving force of calcification in Lake Chiprana mats, the latter group may still contribute to the calcification process by providing nucleation sites. $\mathrm{Nu}-$ cleation sites provided by cyanobacteria (Arp et al. 2001), heterotrophic bacteria (Chafetz and Buczynski 1992; Paerl et al. 2001), and the cell surface of sulfate-reducing bacteria (Van Lith et al. 2003) have been reported. In addition to playing an auxiliary role in calcification by providing nucleation sites, sulfate-reducing bacteria and other heterotrophic bacteria may play an important role by supplying and increasing DIC concentration. Pore-water data show that in Chiprana, this DIC is supplied by diffusion from deeper mat layers to the photic zone, where it is consumed by $\mathrm{CO}_{2}$ fixation and calcification.

\section{References}

Al-Horani, F. A., S. M. Al-Moghrabi, And D. DE Beer. 2003. The mechanism of calcification and its relation to photosyn- 
thesis and respiration in the scleractinian coral Galaxea fascicularis. Mar. Biol. 142: 419-426.

Arp, G., A. ReIMER, AND J. ReITNER. 2001. Photosynthesis-induced biofilm calcification and calcium concentrations in Phanerozoic oceans. Science 292: 1701-1704.

-1, AND $\longrightarrow$ 2003. Microbialite formation in seawater of increased alkalinity, Satonda Crater Lake, Indonesia. J. Sediment. Res. 73: 105-127.

$\longrightarrow,-$ AND $\longrightarrow$ 2004. Microbialite formation in seawater of increased alkalinity, Satonda Crater Lake, Indonesiareply. J. Sediment. Res. 74: 318-325.

Böttcher, M. E., P. L. Gehlken, and D. F. Steele. 1997. Characterization of inorganic and biogenic magnesian calcites by Fourier Transform infrared spectroscopy. Solid State Ionics 101: $1379-1385$.

Canfield, D. E., And D. J. Des Marais. 1991. Aerobic sulfate reduction in microbial mats. Science 251: 1471-1473.

Castanier, S., G. Le Métayer-Levrel, and J. P. Perthuisot, 1999. Ca-carbonates precipitation and limestone genesis-the microbiogeologist point of view. Sediment. Geol. 126: 9-23.

Chafetz, H. S., AND C. BuCZYNSKI. 1992. Bacterially induced lithification of microbial mats. Palaios 7: 277-293.

CranK, J. 1975. The mathematics of diffusion, 2nd ed. Oxford Univ. Press.

De Beer, D., M. Kühl, N. Stambler, and L. Vaki. 2000. A microsensor study of light enhanced $\mathrm{Ca}^{2+}$ uptake and photosynthesis in the reef-building hermatypic coral Favia sp. Mar. Ecol. Prog. Ser. 194: 75-85.

Des Marais, D. J. 1990. Microbial mats and the early evolution of life. Trends Ecol. Evol. 5: 140-144.

Fossing, H., AND B. B. JøRGENSEN. 1989. Measurement of bacterial sulfate reduction in sediments: Evaluation of a single-step chromium reduction method. Biogeochemistry 8: 205-222.

FRÜND, C., AND Y. COHEN. 1992. Diurnal cycles of sulfate reduction under oxic conditions in cyanobacterial mats. Appl. Environ. Microbiol. 58: 70-77.

Garcia-Pichel, F., F. A. Al-Horani, J. D. Farmer, R. Ludwig, AND B. D. WADE. 2004. Balance between microbial calcification and metazoan bioerosion in modern stromatolitic oncolites. Geobiology 2: 49-57.

JONKERS, H. M., AND OTHERS. 2003. Structural and functional analysis of a microbial mat ecosystem from a unique permanent hypersaline inland lake: 'La Salada de Chiprana' (NE Spain). FEMS Microbiol. Ecol. 44: 175-189.

JøRGENSEN, B. B. 1978. A comparison of methods for the quantification of bacterial sulfate reduction in coastal marine sediments. 1. Measurement with radiotracer techniques. Geomicrobiol. J. 1: 11-27.

-1994. Sulfate reduction and thiosulfate transformations in a cyanobacterial mat during a diel oxygen cycle. FEMS Microbiol. Ecol. 13: 303-312.

Kallmeyer, J., T. G. Ferdelman, A. Weber, H. Fossing, and B. B. JøRGENSEN. 2004. A cold chromium distillation procedure for radiolabeled sulfide applied to sulfate reduction measurements. Limnol. Oceanogr. Methods 2: 171-180.

KaZmierczaK, J., AND S. Kempe. 2004. Microbialite formation in seawater of increased alkalinity, Satonda Crater Lake, Indonesia—discussion. J. Sediment. Res. 74: 314-317.

Krumbein, W. E., Y. Cohen, And M. Shilo. 1977. Solar Lake
(Sinai). 4. Stromatolitic cyanobacterial mats. Limnol. Oceanogr. 22: 635-656.

KüHL, M., T. Fenchel, And J. KAZMierczaK. 2003. Growth, structure and calcification potential of an artificial cyanobacterial mat, p. 77-102. In W. Krumbein, D. Paterson, and G. Zavarzin [eds.], Fossil and recent biofilms, a natural history of life on planet Earth. Kluwer.

-, C. Steuckart, G. Eickert, and P. Jeroschewski. 1998. $\mathrm{A}_{2} \mathrm{~S}$ microsensor for profiling biofilms and sediments: Application in an acidic lake sediment. Aquat. Microb. Ecol. 15: 201-209.

LANIECE, P., AND OTHERS. 1998. A new high resolution radioimager for the quantitative analysis of radiolabelled molecules in tissue section. J. Neurosci. Methods 86: 1-5.

LAVAL, B., AND OTHERS. 2000. Modern freshwater microbialite analogues for ancient dendritic reef structures. Nature 407: 626629.

MARGULIS, L., AND OTHERS. 1980. The microbial community in the layered sediments at Laguna Figueroa, Baja California, Mexico: Does it have Precambrian analogues? Precambrian Res. 11: 93-123.

Paerl, H. W., T. F. Steppe, And R. P. Reid. 2001. Bacterially mediated precipitation in marine stromatolites. Environ. Microbiol. 3: 123-130.

REID, R. P., AND OTHERS. 2000. The role of microbes in accretion, lamination and early lithification of modern marine stromatolites. Nature 406: 989-992.

RevsbeCH, N. P. 1989. An oxygen microsensor with a guard cathode. Limnol. Oceanogr. 34: 474-478.

—, AND B. B. JøRGENSEN. 1983. Photosynthesis of benthic microflora measured with high spatial resolution by the oxygen microprofile method: Capabilities and limitations of the method. Limnol. Oceanogr. 28: 749-756.

RIDING, R. 2000. Microbial carbonates: The geological record of calcified bacterial-algal mats and biofilms. Sedimentology 47: $179-214$

Stumm, W., AND J. J. Morgan. 1996. Aquatic chemistry, 3rd ed. Wiley.

VAn Gemerden, H. 1993. Microbial mats-a joint venture. Mar. Geol. 113: 3-25.

Van Lith, Y., R. Warthmann, C. Vasconcelos, and J. A. MCKenZIE. 2003. Microbial fossilization in carbonate sediments: A result of the bacterial surface involvement in dolomite precipitation. Sedimentology 50: 237-245.

Visscher, P. T., R. P. Reid, And B. M. Bebout. 2000. Microscale observations of sulfate reduction: Correlation of microbial activity with lithified micritic laminae in modern marine stromatolites. Geology 28: 919-922.

, -, S. E. Hoeft, I. G. Macintyre, And J. A. ThOMPSON, JR. 1998. Formation of lithified micritic laminae in modern marine stromatolites (Bahamas): The role of sulfur cycling. Am. Miner. 83: 1482-1493.

Wieland, A., AND M. KÜHL. 2000. Short-term temperature effects on oxygen and sulphide cycling in a hypersaline cyanobacterial mat (Solar Lake, Egypt). Mar. Ecol. Prog. Ser. 196: 87-102.

ZeEbe, R. E., AND D. Wolf-Gladrow. 2001. $\mathrm{CO}_{2}$ in seawater: Equilibrium, kinetics, isotopes. Elsevier.

Received: 22 July 2004 Accepted: 25 April 2005 Amended: 8 June 2005 